\title{
Pharmacokinetic targeting of intravenous busulfan reduces conditioning regimen related toxicity following allogeneic hematopoietic cell transplantation for acute myelogenous leukemia
}

Joseph Pidala ${ }^{1,3^{*}}$, Jongphil Kim ${ }^{2,3}$, Claudio Anasetti ${ }^{1,3}$, Mohamed A Kharfan-Dabaja ${ }^{1,3}$, Taiga Nishihori ${ }^{1,3}$, Teresa Field ${ }^{1,3}$, Janelle Perkins ${ }^{1,3}$, Lia Perez ${ }^{1,3}$, Hugo F Fernandez ${ }^{1,3}$

\begin{abstract}
Optimal conditioning therapy for hematopoietic cell transplantation (HCT) in acute myelogenous leukemia (AML) remains undefined. We retrospectively compared outcomes of a consecutive series of $51 \mathrm{AML}$ patients treated with oral busulfan ( $1 \mathrm{mg} / \mathrm{kg}$ every 6 hours for 4 days) and cyclophosphamide $(60 \mathrm{mg} / \mathrm{kg} \mathrm{IV} \times 2$ days) - (Bu/Cy) with 100 consecutive AML patients treated with pharmacokinetic targeted IV busulfan (AUC $<6000 \mu \mathrm{M} / \mathrm{L}^{*} \mathrm{~min}$ per day $\times$ 4 days) and fludarabine ( $40 \mathrm{mg} / \mathrm{m} 2 \times 4$ days) - (t-IV Bu/Flu). The Bu/Cy and t-IV Bu/Flu groups significantly differed according to donor relation, stem cell source, aGVHD prophylaxis, remission status, primary vs. secondary disease, median age, and \% blasts prior to HCT ( $p<0.01$ for each). Conditioning with t-IV Bu/Flu reduced early toxicity including idiopathic pneumonia syndrome (IPS) and hepatic veno-occlusive disease (VOD). Additionally, the trajectory of early NRM (100 day: $16 \%$ vs. $3 \%$, and 1 year: $25 \%$ vs. $15 \%$ for Bu/Cy and t-IV Bu/Flu, respectively) favored t-IV Bu/Flu. Grade II-IV aGVHD (48\% vs. 82\%, p < 0.0001), as well as moderate/severe cGVHD (7\% vs. 40\%, p < 0.0001) differed between the Bu/Cy and t-IV Bu/Flu groups, due to the predominance of peripheral blood stem cells in the t-IV Bu/Flu group. Pharmacokinetic targeting of intravenous busulfan in combination with fludarabine is associated with reduced conditioning regimen related toxicity compared to oral busulfan and cyclophosphamide. However, multivariable analysis did not demonstrate significant differences in overall survival $(p=0.78)$ or non-relapse mortality ( $p=0.6)$ according to conditioning regimen delivered.
\end{abstract}

\section{Background}

Ongoing investigation aims to preserve efficacy, but reduce morbidity and mortality associated with conditioning therapy for allogeneic hematopoietic cell transplantation (HCT). Seminal work has demonstrated variation in bioavailability of oral busulfan $(\mathrm{Bu})$, and the correlation between busulfan exposure and both toxicity including hepatic veno-occlusive disease, [1] as well as graft rejection and primary disease relapse. $(8,9)$ In the setting of both oral and intravenous administration of busulfan, inter-patient variation is observed [2]. Importantly, the intended busulfan exposure differs according

\footnotetext{
* Correspondence: joseph.pidala@moffitt.org 'Department of Blood and Marrow Transplantation, Moffitt Cancer Center, 12902 Magnolia Drive, Tampa, FL, 33612, USA Full list of author information is available at the end of the article

to individual transplantation conditioning regimens, such as $\mathrm{Bu} / \mathrm{Cyclophosphamide(Cy)}$ and $\mathrm{Bu} /$ Fludarabine (Flu). As well, in the context of $\mathrm{Cy} /$ total body irradiation (TBI) based conditioning therapy, McDonald, et al have demonstrated increased non-relapse mortality and reduced overall survival associated with exposure to toxic metabolites of cyclophosphamide [3]. Conversely, fludarabine given in combination with targeted oral [4] or intravenous busulfan $[5,6]$ has been demonstrated safe and effective as conditioning therapy for HCT in myeloid malignancies.

With the intention of reducing transplant related toxicity, as well as expanding access to patients of older age or more advanced comorbidity, a number of reduced to intermediate-intensity, or truly non-myeloablative regimens have been developed [4,5,7-15]. Our center adopted 
an approach of pharmacokinetic-targeted IV Bu/Flu from 2004 onward as a uniform conditioning strategy in the setting of allogeneic transplantation for acute myelogenous leukemia. As the regimen appears to result in reduced treatment related toxicity compared to our center's historical experience with oral busulfan and cyclophosphamide, we aimed to confirm these observations in a comparative analysis of outcomes of AML patients.

\section{Methods}

\section{Patients}

All consecutive acute myelogenous leukemia (AML) patients treated with a conditioning regimen of targeted IV busulfan and fludarabine ( $\mathrm{t}-\mathrm{IV} \mathrm{Bu} / \mathrm{Flu})$ at Moffitt Cancer Center from 2004 to 2008 with a minimum follow up of one year were identified. These were compared to a consecutive historical cohort of 51 consecutive AML patients treated with oral Busulfan and Cyclophosphamide $(\mathrm{Bu} / \mathrm{Cy})$ at the Center from 1997 to 2004. These data demonstrate a trend by which our center's volume of allogeneic transplants for AML have substantially increased over this time frame. As well, supportive care practices and program faculty have changed over this time frame. All patients provided informed consent for follow up of transplant outcome data. The reporting of this data was approved by the University of South Florida Institutional Review Board.

\section{Conditioning, GVHD prophylaxis, and supportive care}

The conditioning regimen in the $\mathrm{t}$-IV $\mathrm{Bu} / \mathrm{Flu}$ group consisted in all cases of Fludarabine, $40 \mathrm{mg} / \mathrm{m}^{2}$ infused over 30 minutes daily on days -6 to -3 , followed by intravenous Busulfan, 130-145 mg/m2 over 4 hours daily on the same days. Busulfan (BU) pharmacokinetic samples were obtained on day -6 and analyzed by mass spectrometry in the clinical toxicology lab at the University of Pennsylvania. Analysis utilized a one compartment model with first order kinetics. On days -4 and -3 , the BU dose was adjusted to target an average AUC of 5300 $(+/-10 \%) \mu \mathrm{Mol}^{*} \min (\mathrm{n}=96)$ or $3500(+/-10 \%) \mu \mathrm{Mol}^{*}-$ $\min (\mathrm{n}=4)$ for each of the four days. The lower target AUC of 3500 was chosen in these 4 cases due to patient age, ranging from 62 to 67 . The $\mathrm{Bu} / \mathrm{Cy}$ regimen consisted in all cases of oral busulfan $1 \mathrm{mg} / \mathrm{kg}$ every 6 hours for 4 days (days -7 to -4 ) for a total of 16 doses, as well as cyclophosphamide $60 \mathrm{mg} / \mathrm{kg}$ IV $\times 2$ days (days -3 to -2). Pharmacokinetic measurements were not performed in this group. Stem cell source and GVHD prophylaxis are reported in table 1.

\section{Outcomes}

Neutrophil engraftment was defined by the first of three successive days with an absolute neutrophil count of greater than $500 / u L$. Platelet engraftment was defined by the first of three successive days with a non-transfused platelet count of greater than 20,000/uL. The occurrence and severity of hepatic sinusoidal obstructive syndrome (veno-occlusive disease) were recorded using the previously described criteria [16,17]. Acute graft vs. host disease (aGVHD) was scored per modified Glucksberg criteria [18]. Chronic graft vs. host disease (cGVHD) was scored per proposed NIH consensus criteria [19]. Peripheral blood sorted (CD3 and CD33) and bone marrow donor chimerism were assessed by PCR. Primary disease restaging occurred in all cases at minimum on days 30 , 90,180 , and 360 , as well as at 18 months, and 2 years.

\section{Statistical analysis}

Differences in baseline characteristics were compared with Wilcoxon rank-sum test for numerical or ordinal variables, and Chi-square test or Fisher exact test for categorical variables. Time to neutrophil and platelet engraftment was calculated using the Kaplan-Meier method; comparison was made with log-rank test. Overall survival (OS) and progression-free survival (PFS) were estimated from date of transplantation using the Kaplan-Meier method; death or relapse was considered an event in the estimation of PFS. Accounting for competing risk events, the cumulative incidence (CI) of relapse and non-relapse mortality (NRM) was calculated by the Gray method [20]. For OS and PFS, baseline variables were examined with univariable, and Cox proportional hazard modeling. For CI of relapse and NRM, a sub-distribution hazards regression model was utilized for univariable and multivariable analysis [21]. For each outcome, distinct models were created to examine preand separately post-HCT variables. Pre-HCT variables considered included the following: conditioning regimen, cytogenetic risk group, donor relation, remission status, number of induction cycles for CR1 patients, stem cell source, GVHD prophylaxis regimen, primary vs. secondary AML, \% blasts in bone marrow immediately prior to HCT, white blood cell count at diagnosis of AML, age at time of HCT, and time in CR1 for those who were transplanted in CR2/3 or with relapsed disease. PostHCT variables considered included the following: maximum grade aGVHD, maximum grade cGVHD, donor chimerism in bone marrow at day 90 post-HCT, and donor CD3 and CD33 chimerism in peripheral blood on day 90 post-HCT. Those variables with $\mathrm{p}$ value of 0.25 or less in univariable analysis were selected for construction of the multivariable model. The backward selection procedure with a p-out value of 0.1 was utilized.

\section{Results}

One hundred consecutive adults with AML received $\mathrm{t}-\mathrm{IV} \mathrm{Bu} / \mathrm{Flu}$, and 51 consecutive AML patients received 
Table 1 Baseline and transplant characteristics of patients in Bu/Cy and t-IV Bu/Flu groups

\begin{tabular}{|c|c|c|c|c|c|}
\hline \multicolumn{2}{|l|}{ Variables } & \multirow[t]{2}{*}{$\begin{array}{c}\mathrm{Bu} / \mathrm{Cy} \\
\text { (Freq/Percent) }\end{array}$} & \multirow[t]{2}{*}{$\begin{array}{c}\text { Bu/Flu } \\
\text { (Freq/Percent) }\end{array}$} & \multirow[t]{2}{*}{$\begin{array}{l}\text { Total } \\
\text { (Freq) }\end{array}$} & \multirow[t]{2}{*}{ P-value } \\
\hline Name & Level & & & & \\
\hline Time from diagnosis to HCT & Months (median value, range) & $6.2(1-29)$ & $6.4(2-54)$ & & 0.5 \\
\hline Follow up time & Months (median value, range) & $8(1-90)$ & $17(1-53)$ & & 0.245 \\
\hline \multirow[t]{3}{*}{ Donor } & MRD & $\begin{array}{c}51 \\
100.00\end{array}$ & $\begin{array}{c}39 \\
39.00\end{array}$ & 81 & $<.0001$ \\
\hline & MUD & $\begin{array}{c}0 \\
0.00\end{array}$ & $\begin{array}{c}39 \\
39.00\end{array}$ & 39 & \\
\hline & MMUD & $\begin{array}{c}0 \\
0.00\end{array}$ & $\begin{array}{c}22 \\
22.00\end{array}$ & 22 & \\
\hline \multirow[t]{3}{*}{ Cytogenetic } & Low & $\begin{array}{c}3 \\
7.89\end{array}$ & $\begin{array}{c}7 \\
7.00\end{array}$ & 10 & 0.3568 \\
\hline & Intermediate & $\begin{array}{c}25 \\
65.79\end{array}$ & $\begin{array}{c}54 \\
54.00\end{array}$ & 79 & \\
\hline & High & $\begin{array}{c}10 \\
26.32\end{array}$ & $\begin{array}{c}39 \\
39.00\end{array}$ & 49 & \\
\hline \multirow[t]{2}{*}{ ATG } & No & $\begin{array}{c}42 \\
100.00\end{array}$ & $\begin{array}{c}78 \\
78.79\end{array}$ & 120 & 0.0006 \\
\hline & Yes & $\begin{array}{c}0 \\
0.00\end{array}$ & $\begin{array}{c}20 \\
20.20\end{array}$ & 20 & \\
\hline \multirow[t]{2}{*}{ Cell Source } & BM & $\begin{array}{c}35 \\
68.63\end{array}$ & $\begin{array}{c}2 \\
2.00\end{array}$ & 37 & $<.0001$ \\
\hline & PB & $\begin{array}{c}16 \\
31.37\end{array}$ & $\begin{array}{c}98 \\
98.00\end{array}$ & 114 & \\
\hline \multirow[t]{4}{*}{ aGVHD prophylaxis } & CSA/MTX & $\begin{array}{c}51 \\
100.00\end{array}$ & $\begin{array}{c}0 \\
0.00\end{array}$ & 42 & $<.0001$ \\
\hline & TAC/MMF & $\begin{array}{c}0 \\
0.00\end{array}$ & $\begin{array}{c}22 \\
22.00\end{array}$ & 22 & \\
\hline & TAC/MTX & $\begin{array}{c}0 \\
0.00\end{array}$ & $\begin{array}{c}77 \\
71.00\end{array}$ & 77 & \\
\hline & TAC/RAPA & $\begin{array}{c}0 \\
0.00\end{array}$ & $\begin{array}{c}1 \\
1.00\end{array}$ & 1 & \\
\hline \multirow[t]{5}{*}{ Disease Status } & CR1 & $\begin{array}{c}19 \\
37.25\end{array}$ & $\begin{array}{c}49 \\
49.00\end{array}$ & 68 & 0.0013 \\
\hline & CR2 or CR3 & $\begin{array}{c}6 \\
11.76\end{array}$ & $\begin{array}{c}25 \\
25.00\end{array}$ & 31 & \\
\hline & PIF & $\begin{array}{c}7 \\
13.73\end{array}$ & $\begin{array}{c}16 \\
16.00\end{array}$ & 23 & \\
\hline & Relapse & $\begin{array}{c}18 \\
35.29\end{array}$ & $\begin{array}{c}9 \\
9.00\end{array}$ & 27 & \\
\hline & UNT & $\begin{array}{c}1 \\
1.96\end{array}$ & $\begin{array}{c}1 \\
1.00\end{array}$ & 2 & \\
\hline \multirow[t]{2}{*}{ Diagnosis } & primary & $\begin{array}{c}41 \\
80.39\end{array}$ & $\begin{array}{c}62 \\
62.00\end{array}$ & 103 & 0.0221 \\
\hline & secondary & $\begin{array}{c}10 \\
19.61\end{array}$ & $\begin{array}{c}38 \\
38.00\end{array}$ & 48 & \\
\hline \multirow[t]{4}{*}{ No of Induction } & 0 & $\begin{array}{c}1 \\
2.38\end{array}$ & $\begin{array}{c}1 \\
1.00\end{array}$ & 2 & 0.4882 \\
\hline & 1 & $\begin{array}{c}31 \\
73.81\end{array}$ & $\begin{array}{c}67 \\
67.00\end{array}$ & 98 & \\
\hline & 2 & $\begin{array}{c}9 \\
21.43\end{array}$ & $\begin{array}{c}24 \\
24.00\end{array}$ & 33 & \\
\hline & 3 & $\begin{array}{c}1 \\
2.38\end{array}$ & $\begin{array}{c}8 \\
8.00\end{array}$ & 9 & \\
\hline AGE & & $39.0(19.6-55.60)$ & $48.16(21.84-68.64)$ & & 0.0001 \\
\hline WBC at Diagnosis & & 13.60 (0.80-190.00) & $5.80(0.25-285.00)$ & & 0.1073 \\
\hline Time in CR1 & & $256(12-762)$ & 324.5 (21 - 2679) & & 0.1699 \\
\hline$\%$ Blast in $\mathrm{BM}$ & & $4(0-88)$ & $2(0-80)$ & & 0.0028 \\
\hline \multirow[t]{3}{*}{ Chimerism (day 90) } & BM & $100(55-100)$ & $97(10-100)$ & & 0.0925 \\
\hline & CD3 & NA & $90(18-100)$ & & NA \\
\hline & CD33 & NA & $100(10-100)$ & & NA \\
\hline
\end{tabular}


oral busulfan without PK targeting and cyclophosphamide $(\mathrm{Bu} / \mathrm{Cy})$. The $\mathrm{t}-\mathrm{IV} \mathrm{Bu} / \mathrm{Flu}$ conditioning regimen incorporated fludarabine, $40 \mathrm{mg} / \mathrm{m}^{2}$ infused over 30 minutes on days -6 to -3 , then intravenous busulfan, $130-145 \mathrm{mg} / \mathrm{m} 2$ over 4 hours daily on the same days. Busulfan $(\mathrm{Bu})$ PK-samples were obtained on day -6 and analyzed by mass spectrometry; the BU dose was adjusted on days -4 and -3 to achieve an overall average AUC of $5300(+/-10 \%) \mu \mathrm{Mol}^{*} \min (\mathrm{n}=96)$ or 3500 $(+/-10 \%) \mu \mathrm{Mol}^{*} \mathrm{~min}(\mathrm{n}=4)$ for each of the four days. The median actual AUC after the first dose was 5113 $\mu \mathrm{M}^{*}$ min (range 2796 - 9355) for the $5300 \mu \mathrm{M}^{*}$ min target subgroup and $4244 \mathrm{uM}^{*} \mathrm{~min}$ (range 2830 - 5347) for the $3500 \mu \mathrm{M}$ *min target subgroup. Daily busulfan doses were adjusted to achieve the target AUC averaged over 4 days. Median total $\mathrm{BU}$ dose required to achieve the target AUC was $520 \mathrm{mg} / \mathrm{m}^{2}$ (range 370 - 974) in the $5300 \mu \mathrm{M} / \mathrm{L}^{*} \mathrm{~min}$ group and $418 \mathrm{mg} / \mathrm{m}^{2}$ (range 254 $470)$ in the $3500 \mu \mathrm{M} / \mathrm{L} * \mathrm{~min}$ group. Baseline characteristics are summarized in table 1 . Importantly, there were significant differences across the following baseline characteristics in the $\mathrm{Bu} / \mathrm{Cy}$ and $\mathrm{t}-\mathrm{IV} \mathrm{Bu} / \mathrm{Flu}$ groups: donor relation, stem cell source, aGVHD prophylaxis, remission status, primary vs. secondary disease, median age, and \% blasts prior to HCT.

\section{Comparison of $\mathrm{Bu} / \mathrm{Cy}$ vs. t-IV Bu/Flu: composite groups}

Median time to neutrophil engraftment was 18 vs. 16 days $(\mathrm{p}<0.001)$, and median time to platelet engraftment was 21 vs. 12 days $(\mathrm{p}=0.0002)$ for $\mathrm{Bu} / \mathrm{Cy}$ and $\mathrm{t}$-IV Bu/Flu, respectively. Differences in engraftment are attributable to the preponderance of peripheral blood stem cells (PBSC) in the t-IV Bu/Flu group. There was a greater burden of conditioning regimen related toxicity observed after $\mathrm{Bu} / \mathrm{CY}$ : There were 5 fatal cases of IPS and 6 cases (mild 1; moderate 4; and severe, fatal case 1) of VOD after conditioning with $\mathrm{Bu} / \mathrm{Cy}$. Conversely, in the $\mathrm{t}-\mathrm{IV} \mathrm{Bu} / \mathrm{Flu}$ group there was one case of idiopathic pneumonia syndrome (IPS) and no cases of hepatic sinusoidal obstructive syndrome (VOD). While the ultimate CI of non-relapse mortality (NRM) did not significantly differ between groups (figure 1), early NRM was reduced in the $\mathrm{t}-\mathrm{IV} \mathrm{Bu} /$ Flu group (table 2).

There were significant differences in grade II-IV aGVHD ( $48 \%$ vs. $82 \%$, p $<0.0001$ ), as well as moderate/severe cGVHD (7\% vs. $40 \%, \mathrm{p}<0.0001)$ between the $\mathrm{Bu} / \mathrm{Cy}$ and $\mathrm{t}$-IV $\mathrm{Bu} /$ Flu groups, respectively; the marked increase in the incidence of GVHD observed in the t-IV Bu/Flu arm is attributable to the greater proportion of PBSC. The disparity in NRM in the first year after HCT suggests less conditioning regimen toxicity after $\mathrm{t}$-IV Bu/Flu. However, NRM trends toward convergence over 1 and 2 years, likely secondary to this increased risk of GVHD.
With median follow up for living patients of 54 months (range 11 - 90) for $\mathrm{Bu} / \mathrm{CY}$ and 28 months (range CI 2 54) for t-IV Bu/Flu, median OS was 8 months (95\% CI 5.4 - 22) vs. 21 months (95\% CI 10.9 - not reached), respectively for each group (figure 2). Causes of death for $\mathrm{Bu} / \mathrm{Cy}$ were: infection $(\mathrm{n}=4)$, relapse $(\mathrm{n}=22)$, idiopathic pneumonia syndrome $(n=5)$, hepatic $\operatorname{VOD}(n=1)$, multi-system organ failure $(\mathrm{n}=1)$, unknown $(\mathrm{n}=1)$, and TTP/HUS $(n=1)$. Causes of death in the t-IV Bu/Flu group included: refractory aGVHD $(\mathrm{n}=4)$, refractory cGVHD $(n=1)$, infection $(n=7)$, relapse $(n=29)$, multiorgan system failure $(n=7)$, post-transplant lymphoproliferative disorder $(\mathrm{n}=1)$, and unknown $(\mathrm{n}=3)$. Median PFS was 6.9 months $(95 \% \mathrm{CI} 4.1-20)$ in the $\mathrm{Bu} / \mathrm{Cy}$ group vs. 15.1 months (95\% CI 9.1 - 30) in the t-IV Bu/ Flu group. There was no significant difference in the cumulative incidence of AML relapse at day 100 (16\% vs. $17 \%), 1$ year (33\% vs. $32 \%$ ), or 2 years ( $40 \%$ vs. $37 \%$ ) after $\mathrm{HCT}$ in the comparison of $\mathrm{Bu} / \mathrm{Cy}$ vs. t-IV Bu/Flu, respectively, $\mathrm{p}=0.68$.

\section{Comparison $\mathrm{Bu} / \mathrm{Cy}$ vs. t-IV Bu/Flu according to disease risk subgroups \\ Complete remission 1 (CR1)}

Nineteen patients received $\mathrm{Bu} / \mathrm{Cy}$ in $\mathrm{CR} 1$, and 49 received $\mathrm{t}-\mathrm{IV} \mathrm{Bu} / \mathrm{Flu}$ in $\mathrm{CR} 1$. The proportion with primary vs. secondary AML in CR1 $(\mathrm{Bu} / \mathrm{Cy}$ : primary $\mathrm{n}=13$, secondary $\mathrm{n}=6$; $\mathrm{t}-\mathrm{IV} \mathrm{Bu} / \mathrm{Flu}$ : primary $\mathrm{n}=30$, secondary $\mathrm{n}=19$, Fisher exact $\mathrm{p}=0.78$ ) and cytogenetic risk group $(\mathrm{Bu} / \mathrm{Cy}$ : low $\mathrm{n}=0$, intermediate $\mathrm{n}=10$, high $\mathrm{n}=3, \mathrm{n} / \mathrm{a} \mathrm{n}$ $=6$; $\mathrm{t}-\mathrm{IV} \mathrm{Bu} /$ Flu: low $\mathrm{n}=2$, intermediate $\mathrm{n}=26$, high $\mathrm{n}=$ 21 , Fisher exact $\mathrm{p}=0.28$ ) did not significantly differ between the $\mathrm{Bu} / \mathrm{Cy}$ and $\mathrm{t}-\mathrm{IV} \mathrm{Bu} / \mathrm{Flu}$ groups. There was no significant difference in OS between these groups (1 year OS $63 \%$ vs. $63 \%$, and 2 year OS $63 \%$ and $58 \%$ for $\mathrm{Bu} / \mathrm{Cy}$ vs. $\mathrm{t}-\mathrm{IV} \mathrm{Bu} / \mathrm{Flu}, \mathrm{p}=0.78$ ) respectively (figure 3 ). There was also no significant difference between groups for those with primary AML in CR1 (1 year OS 69\% vs. $66 \%, 2$ year OS $69 \%$ vs. $62 \%$ for Bu/Cy vs. t-IV Bu/Flu, p $=0.8)$ and those with secondary AML in CR1 (1 year OS $69 \%$ vs. $66 \%, 2$ year OS $69 \%$ vs. $62 \%$ for Bu/Cy vs. t-IV $\mathrm{Bu} / \mathrm{Flu}, \mathrm{p}=0.9)$. As well, there was a non-significant increase in early non-relapse mortality in the $\mathrm{Bu} / \mathrm{Cy}$ group ( 100 day $21 \%$ vs. $4 \%, 1$ year $26 \%$ vs. $16 \%$, and 2 year $26 \%$ vs. $21 \%, \mathrm{p}=0.98)$.

\section{Complete remission 2 or 3 (CR2/3)}

Six patients received $\mathrm{Bu} / \mathrm{Cy}$ conditioning in $\mathrm{CR} 2 / 3$ and 25 patients received t-IV Bu/Flu conditioning in CR 2/3. $\mathrm{OS}$ was significantly worse in those in the $\mathrm{Bu} / \mathrm{Cy}$ group ( 1 year OS $17 \%$ vs. $59 \%, 2$ year OS $17 \%$ vs. $41 \%$ for $\mathrm{Bu} /$ $\mathrm{Cy}$ vs. t-IV Bu/Flu, $\mathrm{p}=0.03)$. NRM (100 day $0 \%$ vs. $0 \%$, 1 year $50 \%$ vs. $16 \%$, and 2 years $50 \%$ vs. $24 \%$ for $\mathrm{Bu} / \mathrm{Cy}$ vs. $\mathrm{t}-\mathrm{IV} \mathrm{Bu} / \mathrm{Flu}, \mathrm{p}=0.14$ ) did not significantly differ. 


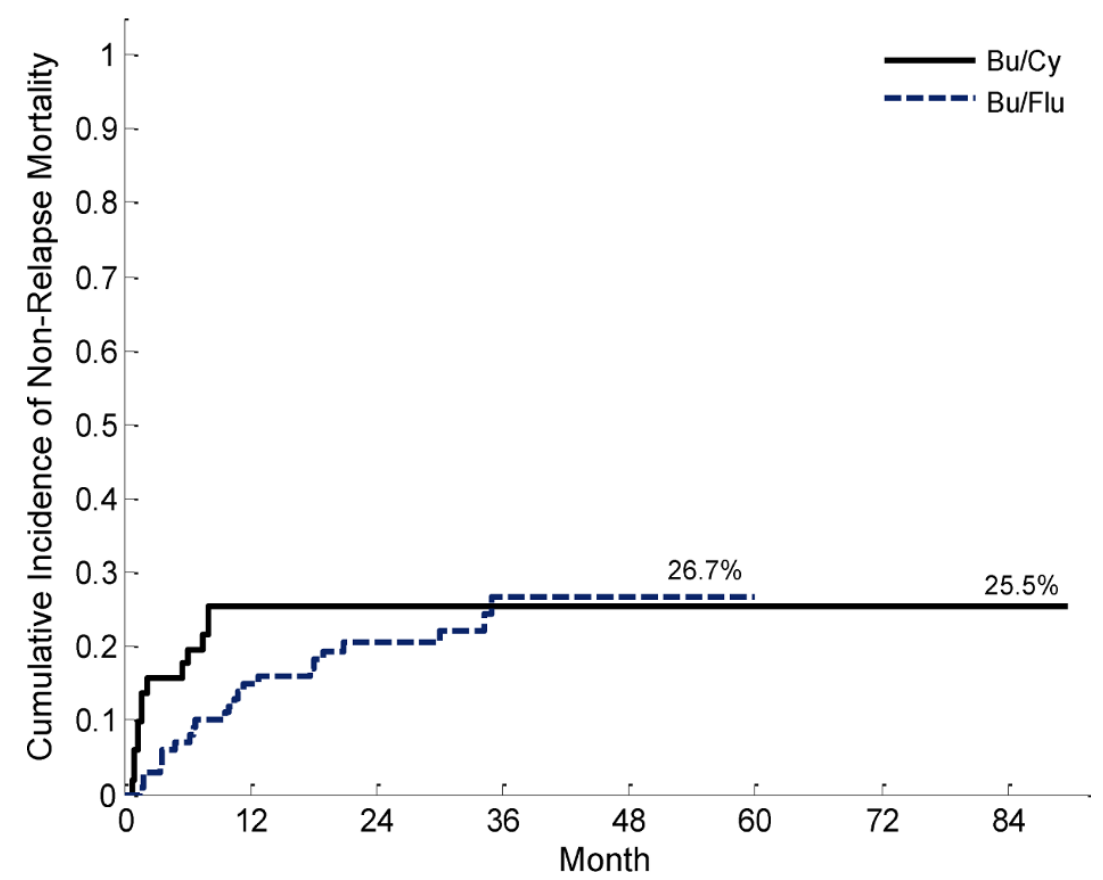

Figure 1 Cumulative incidence of NRM according to conditioning regimen $(p=0.65)$.

\section{Primary induction failure (PIF)}

Seven patients received $\mathrm{Bu} / \mathrm{CY}$ as conditioning in the setting of primary induction failure, and 16 patients received t-IV Bu/Flu. OS significantly differed (1 year OS 29\% vs. 69\%, 2 year OS $14 \%$ vs. $61 \%$ for Bu/Cy vs. t-IV Bu/Flu, $\mathrm{p}=0.01$ ) between groups. NRM (100 day $0 \%$ vs. $0 \%, 1$ year $14 \%$ vs. $6 \%$, and 2 year $14 \%$ vs. $6 \%$ for $\mathrm{Bu} / \mathrm{Cy}$ vs. $\mathrm{t}-\mathrm{IV}$ $\mathrm{Bu} / \mathrm{Flu}, \mathrm{p}=0.58$ ) did not significantly differ.

\section{Refractory relapsed disease}

Eighteen patients with refractory relapsed AML were treated with $\mathrm{Bu} / \mathrm{Cy}$, and 9 received $\mathrm{t}$-IV Bu/Flu. There was no significant difference in OS (1 year OS 33\% vs. $22 \%$, 2 year OS $17 \%$ vs. $0 \%$ for Bu/Cy vs. t-IV Bu/Flu, $\mathrm{p}=$ 0.52 ). NRM (100 day $22 \%$ vs. $11 \%, 1$ year $22 \%$ vs. $22 \%$, and 2 year $22 \%$ vs. n/a for Bu/Cy vs. t-IV Bu/Flu, $\mathrm{p}=0.61$ ) did not significantly differ between groups.

\section{Multivariable modeling}

Baseline pre-transplant variables were first considered in univariable analysis to evaluate the relationship of each with OS. In the multivariable model, only relapsed

Table 2 Non-relapse mortality according to treatment regimen

\begin{tabular}{lll}
\hline & t-IV Bu/Flu & Bu/Cy \\
\hline 100 days & $3 \%$ & $16 \%$ \\
6 months & $7 \%$ & $18 \%$ \\
1 year & $15 \%$ & $25 \%$
\end{tabular}

disease at time of HCT remained a significant predictor of OS, HR 3.3 (95\% CI 1.4 - 7.9; p = 0.007). Conditioning regimen did not significantly predict OS. In multivariable analysis of post-HCT variables, moderate/severe cGVHD - HR of 0.4 (95\% CI $0.18-0.88$; p = 0.02) - and day 90 bone marrow chimerism $\geq 90 \%-$ HR of 0.28 (95\% CI 0.11 - 0.71; p = 0.008) - predicted OS.

Baseline variables were also examined in univariable analysis to discern their relationship with progressionfree survival. On construction of a multivariable model using pre-HCT variables, remission status emerged as an independent predictor of PFS. In reference to CR1, refractory relapsed disease predicted significantly worse PFS, with HR 3.0 (95\% CI 1.3 - 7; p = 0.01). Conditioning regimen did not significantly predict PFS. Examination of post-HCT variables in multivariable modeling identified day $90 \mathrm{BM}$ chimerism $\geq 90 \%$ as a significant predictor: HR 0.18 (95\% CI 0.08 - 0.42; p < 0.0001).

In multivariable analysis of pre-HCT variables, relapse was significantly predicted by remission status: PIF (HR 3.0, 95\% CI $1.2-7.5, \mathrm{p}=0.015)$ and refractory relapsed disease (HR 3.8, 95\% CI 1.4 - 10.3, p = 0.009) were associated with significantly greater risk of relapse compared to a reference of CR1. Conditioning regimen did not significantly predict relapse. Of post-HCT variables, multivariable modeling identified day $90 \mathrm{BM}$ chimerism $\geq 90 \%$ as a protective factor (HR 0.16, 95\% CI $0.08-0.35, \mathrm{p}<0.001$ ).

Finally, of pre-HCT variables, peripheral blood stem cells were associated with less NRM (HR 0.34, 95\% 


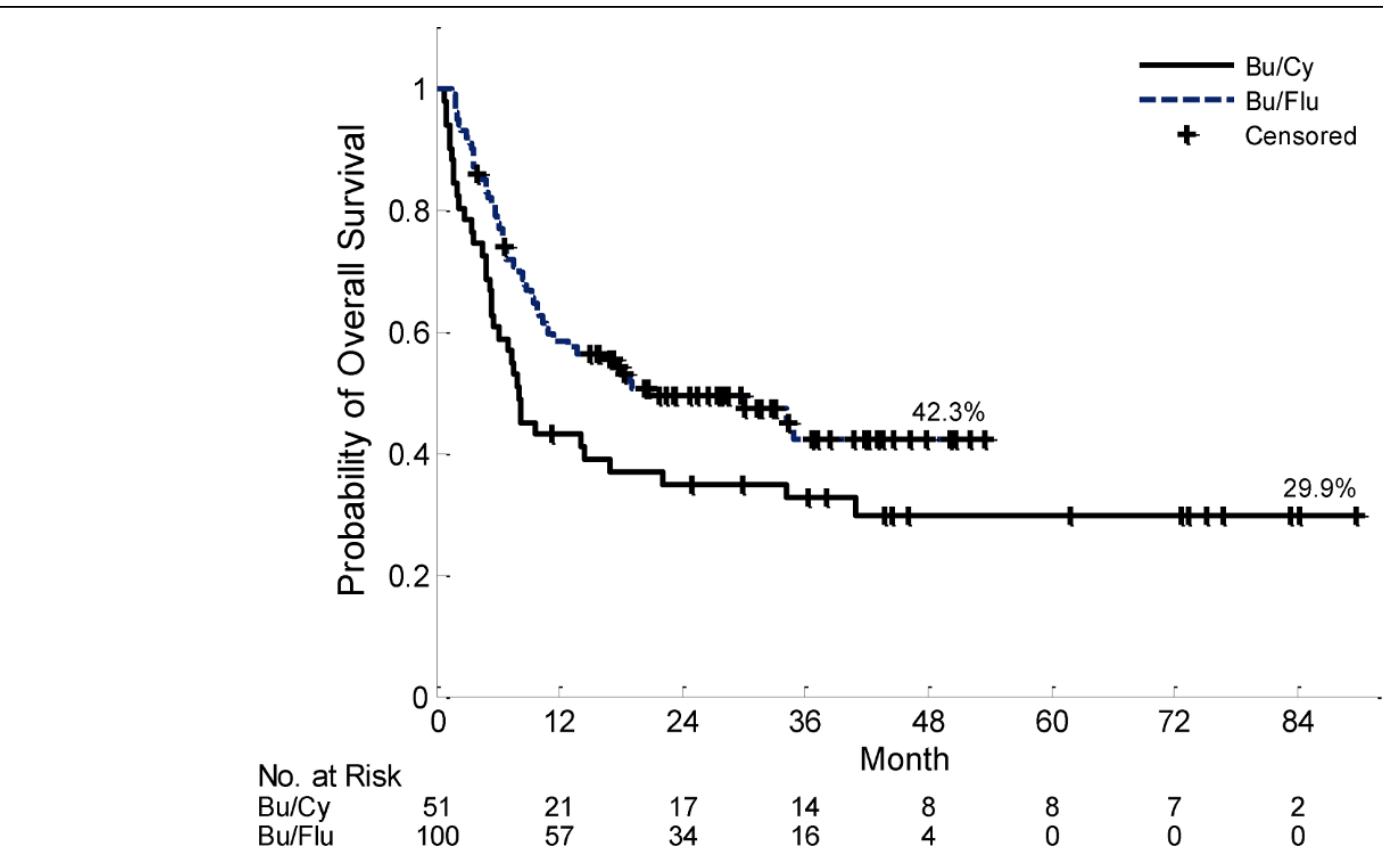

Figure 2 Overall survival for total sample in $\mathrm{Bu} / \mathrm{Cy}$ and t-IV Bu/Flu groups (log-rank $\mathrm{p}=0.0356$ )

CI $0.12-0.98, \mathrm{p}=0.046)$, as compared to a reference of bone marrow stem cells in multivariable analysis. Additionally, with reference of TAC/MMF aGVHD prophylaxis, both CSA/MTX (HR 0.18, 95\% CI 0.05 $0.63, \mathrm{p}=0.01)$ and TAC/MTX (HR 0.41, 95\% CI 0.18 $0.93, \mathrm{p}=0.03)$ predicted significantly lower NRM on multivariable modeling. There was a trend toward decreased NRM in the t-IV Bu/Flu group (HR 0.83,
95\% CI 0.41 - 1.7, $\mathrm{p}=0.6)$ compared to $\mathrm{Bu} / \mathrm{Cy}$ in univariable analysis, which did not remain a significant predictor of NRM on multivariable modeling. Of post-HCT variables examined in uni- and multi-variable analysis, grade III/IV aGVHD demonstrated a non-significant trend toward greater NRM (HR 2.7, $95 \%$ CI $0.99-7.2, \mathrm{p}=0.053)$, as compared to a reference of grade $0 / \mathrm{I}$.

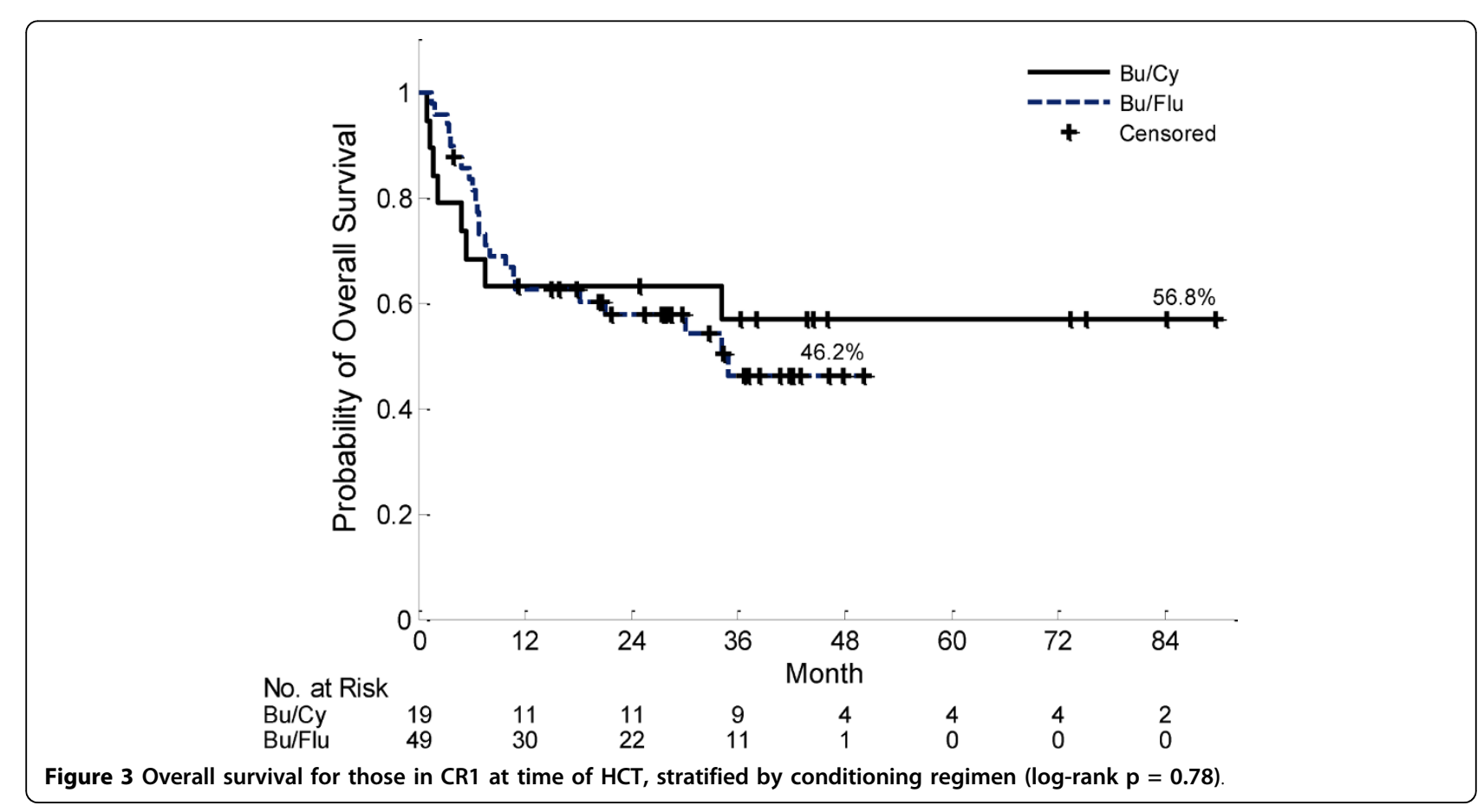




\section{Discussion}

Recognizing the adverse outcomes potentiated by variation in bioavailability of oral busulfan, as well as increased toxicity from aberrant metabolism of cyclophosphamide, there was a shift in the institutional practice at our center, wherein those consecutive AML patients transplanted from 2004 onward received intravenous PK-targeted busulfan combined with fludarabine ( $\mathrm{t}-\mathrm{IV} \mathrm{Bu} / \mathrm{Flu}$ ) as conditioning therapy. We aimed to compare these outcomes to a historical cohort of AML patients, who received $\mathrm{Bu} / \mathrm{Cy}$ as conditioning therapy in a single institution.

The most consistent finding from this analysis is the reduction in conditioning regimen related toxicity as well as reduction in early transplant related mortality with the adoption of $\mathrm{t}-\mathrm{IV} \mathrm{Bu}$ /Flu. A near elimination of severe busulfan toxicity including idiopathic pneumonia syndrome and hepatic veno-occlusive disease represents a major advantage in early HCT outcomes favoring t-IV $\mathrm{Bu} / \mathrm{Flu}$. These data corroborate the reduction in conditioning regimen toxicity anticipated with both pharmacokinetic targeting of busulfan, and avoidance of cyclophosphamide and it metabolites [3]. As well, while the ultimate cumulative incidence of NRM did not significantly differ between the t-IV Bu/Flu and $\mathrm{Bu} / \mathrm{Cy}$ groups, the trajectory of NRM differed with less NRM at day 100 and 1 year in the $\mathrm{t}-\mathrm{IV} \mathrm{Bu}$ /Flu group. The significantly greater burden of aGVHD and severe cGVHD in the $\mathrm{t}-\mathrm{IV} \mathrm{Bu} / \mathrm{Flu}$ group, explained by the predominance of peripheral blood stem cells, burden of unrelated and mismatched unrelated donors, and older age, resulted in the later approximation of these NRM curves. We acknowledge that these data on trends in early NRM and GVHD related outcomes are likely dependent upon the predominance of peripheral blood stem cells in the t-IV Bu/Flu group.

Of the $100 \mathrm{AML}$ patients treated with t-IV Bu/Flu and 51 treated with $\mathrm{Bu} / \mathrm{Cy}$, there were important differences in baseline variables which circumscribe other comparisons. First, transplant conditions differed, which complicates observed differences in non-relapse mortality between groups: While the $\mathrm{Bu} / \mathrm{Cy}$ group only included matched sibling donors, the t-IV Bu/Flu group included matched sibling donors, but the majority $(61 \%)$ were either unrelated or mismatched unrelated donors. This in particular, as well as the significantly increased age and predominance of peripheral blood stem cells ( $98 \%$ of subjects) in the $\mathrm{t}-\mathrm{IV} \mathrm{Bu} / \mathrm{Flu}$ group likely account for the significantly increased grade II-IV aGVHD and moderate/severe cGVHD realized in the t-IV Bu/Flu group. Second, the $\mathrm{Bu} / \mathrm{Cy}$ and $\mathrm{t}$-IV $\mathrm{Bu} / \mathrm{Flu}$ groups differ according to disease risk variables, with a greater proportion of refractory relapsed disease at $\mathrm{HCT}$ in the $\mathrm{Bu} / \mathrm{Cy}$ group, and conversely a greater proportion with secondary AML in the t-IV $\mathrm{Bu} / \mathrm{Flu}$ group. The net effect of these disparate transplant and disease risk variables is difficult to discern. Accordingly, we have reported outcomes according to remission status, and also examined these variables in uni- and multi-variable modeling to discern the impact of conditioning regimen on outcome.

Acknowledging differences in disease risk variables between groups as well as the predominant use of PBSC in the $\mathrm{t}$-IV $\mathrm{Bu} / \mathrm{Flu}$ group, these results do not demonstrate significant differences in disease control between the two approaches. The cumulative incidence of relapse observed across groups both in the overall sample, as well as for each remission status subgroup, was similar. As well, conditioning regimen was not significantly associated with relapse on multivariable modeling. Specific conclusions regarding the impact of conditioning regimen on disease control among specific remission status groups are limited by small sample sizes. The most important predictor of relapse post-HCT in this series of AML patients was remission status at the time of HCT.

In total, these results demonstrate a reduction in conditioning regimen related toxicity and mortality after $\mathrm{t}-\mathrm{IV} \mathrm{Bu} / \mathrm{Flu}$ for $\mathrm{HCT}$ in a consecutive series of adult AML patients. Previously published retrospective comparisons between comparable regimens of IV $\mathrm{Bu} /$ Flu and $\mathrm{Bu} / \mathrm{Cy}$ have also demonstrated reduced toxicity in keeping with the conclusions of our analysis. In a retrospective analysis, Andersson, et al compared IV $\mathrm{Bu} / \mathrm{Flu}$ and IV $\mathrm{Bu} / \mathrm{Cy} 2$ as conditioning therapy for AML and MDS; groups differed significantly, with older age and a greater proportion of unrelated donors in the IV Bu/Flu group. Overall survival was significantly better in the IV Bu/Flu group [22]. Bredeson, et al compared IV Flu/Bu/ATG to oral Bu/Cy in a matched pair analysis compared to registry data including a heterogeneous array of hematologic malignancies; the Flu/Bu/ATG group had significantly older age, worse performance status, greater proportion of PBSC, and was transplanted in a later time period. This analysis demonstrated significantly decreased NRM in the Flu/Bu/ATG group [23]. Finally, Chae, et al compared IV $\mathrm{Bu} / \mathrm{Flu}$ and oral $\mathrm{Bu} / \mathrm{Cy} 2$; patient age was significantly greater in the IV Bu/Flu group. NRM was lower, and overall survival was significantly greater in the IV Bu/Flu group [24]. Overall, these retrospective comparisons suggest a significant advantage in transplantation outcomes favoring IV Bu/Flu. Randomized clinical trial data is needed to determine the true benefit of IV Bu/Flu over $\mathrm{Bu} / \mathrm{Cy}$ conditioning for allogeneic HCT in acute myelogenous leukemia. 


\section{Author details}

'Department of Blood and Marrow Transplantation, Moffitt Cancer Center, 12902 Magnolia Drive, Tampa, FL, 33612, USA. ${ }^{2}$ Department of Biostatistics, Moffitt Cancer Center, 12902 Magnolia Drive, Tampa, FL, 33612, USA. ${ }^{3}$ Department of Oncological Sciences, University of South Florida, Tampa, FL 33612, USA

\section{Authors' contributions}

All authors have read and approved this manuscript. JP designed the project, collected data, analyzed data, and wrote the manuscript; JK contributed to data analysis; CA contributed to design of project, analysis, and critical review of manuscript; MKD contributed to analysis and critical review of manuscript; TN contributed to analysis and critical review of manuscript; TF contributed to analysis and critical review of manuscript; JP contributed to analysis and critical review of manuscript; LP contributed to analysis and critical review of manuscript; and HF contributed to design of project, analysis, and critical review of manuscript.

\section{Competing interests}

The authors report the following funding sources which have relevance to the work described here: Claudio Anasetti, MD, and Janelle Perkins, PharmD have research funding from Protein Design Labs BioPharma for the conduct of research involving busulfan and fludarabine as conditioning therapy prior to allogeneic transplantation.

Received: 13 September 2010 Accepted: 6 October 2010

Published: 6 October 2010

\section{References}

1. Dix SP, Wingard JR, Mullins RE, Jerkunica I, Davidson TG, Gilmore CE, York RC, Lin LS, Devine SM, Geller RB, Heffner LT, Hillyer CD, Holland HK Winton EF, Saral R: Association of busulfan area under the curve with veno-occlusive disease following BMT. Bone Marrow Transplant 1996, 17:225-230.

2. McCune JS, Holmberg LA: Busulfan in hematopoietic stem cell transplant setting. Expert Opin Drug Metab Toxicol 2009, 5:957-969.

3. McDonald GB, Slattery JT, Bouvier ME, Ren S, Batchelder AL, Kalhorn TF, Schoch HG, Anasetti C, Gooley T: Cyclophosphamide metabolism, liver toxicity, and mortality following hematopoietic stem cell transplantation. Blood 2003, 101:2043-2048.

4. Bornhauser M, Storer B, Slattery JT, Appelbaum FR, Deeg HJ, Hansen J, Martin PJ, McDonald GB, Nichols WG, Radich J, Woolfrey A, Jenke A, Schleyer E, Thiede C, Ehninger G, Anasetti C: Conditioning with fludarabine and targeted busulfan for transplantation of allogeneic hematopoietic stem cells. Blood 2003, 102:820-826.

5. de Lima M, Couriel D, Thall PF, Wang X, Madden T, Jones R, Shpall EJ, Shahjahan M, Pierre B, Giralt S, Korbling M, Russell JA, Champlin RE, Andersson BS: Once-daily intravenous busulfan and fludarabine: clinical and pharmacokinetic results of a myeloablative, reduced-toxicity conditioning regimen for allogeneic stem cell transplantation in AML and MDS. Blood 2004, 104:857-864.

6. Russell JA, Tran HT, Quinlan D, Chaudhry A, Duggan P, Brown C, Stewart D, Ruether JD, Morris D, Glick S, Gyonyor E, Andersson BS: Once-daily intravenous busulfan given with fludarabine as conditioning for allogeneic stem cell transplantation: study of pharmacokinetics and early clinical outcomes. Biol Blood Marrow Transplant 2002, 8:468-476.

7. Tauro S, Craddock C, Peggs K, Begum G, Mahendra P, Cook G, Marsh J, Milligan D, Goldstone A, Hunter A, Khwaja A, Chopra R, Littlewood T, Peniket A, Parker A, Jackson G, Hale G, Cook M, Russell N, Mackinnon S: Allogeneic stem-cell transplantation using a reduced-intensity conditioning regimen has the capacity to produce durable remissions and long-term disease-free survival in patients with high-risk acute myeloid leukemia and myelodysplasia. J Clin Oncol 2005, 23:9387-9393.

8. van Besien K, Artz A, Smith S, Cao D, Rich S, Godley L, Jones D, Del Cerro P, Bennett D, Casey B, Odenike O, Thirman M, Daugherty C, Wickrema A, Zimmerman T, Larson RA, Stock W: Fludarabine, melphalan, and alemtuzumab conditioning in adults with standard-risk advanced acute myeloid leukemia and myelodysplastic syndrome. J Clin Oncol 2005, 23:5728-5738.

9. Schmid C, Schleuning M, Ledderose G, Tischer J, Kolb HJ: Sequential regimen of chemotherapy, reduced-intensity conditioning for allogeneic stem-cell transplantation, and prophylactic donor lymphocyte transfusion in high-risk acute myeloid leukemia and myelodysplastic syndrome. J Clin Oncol 2005, 23:5675-5687.

10. Schmid C, Schleuning M, Hentrich M, Markl GE, Gerbitz A, Tischer J, Ledderose G, Oruzio D, Hiddemann W, Kolb HJ: High antileukemic efficacy of an intermediate intensity conditioning regimen for allogeneic stem cell transplantation in patients with high-risk acute myeloid leukemia in first complete remission. Bone Marrow Transplant 2008, 41:721-727.

11. Schmid C, Schleuning M, Schwerdtfeger R, Hertenstein B, MischakWeissinger E, Bunjes D, Harsdorf SV, Scheid C, Holtick U, Greinix H, Keil F, Schneider B, Sandherr M, Bug G, Tischer J, Ledderose G, Hallek M, Hiddemann W, Kolb HJ: Long-term survival in refractory acute myeloid leukemia after sequential treatment with chemotherapy and reducedintensity conditioning for allogeneic stem cell transplantation. Blood 2006, 108:1092-1099.

12. Blaise DP, Michel Boiron J, Faucher C, Mohty M, Bay JO, Bardoux VJ, Perreau V, Coso D, Pigneux A, Vey N: Reduced intensity conditioning prior to allogeneic stem cell transplantation for patients with acute myeloblastic leukemia as a first-line treatment. Cancer 2005, 104:1931-1938.

13. Sayer HG, Kroger M, Beyer J, Kiehl M, Klein SA, Schaefer-Eckart K, Schwerdtfeger R, Siegert W, Runde V, Theuser C, Martin H, Schetelig J, Beelen DW, Fauser A, Kienast J, Hoffken K, Ehninger G, Bornhauser M: Reduced intensity conditioning for allogeneic hematopoietic stem cell transplantation in patients with acute myeloid leukemia: disease status by marrow blasts is the strongest prognostic factor. Bone Marrow Transplant 2003, 31:1089-1095.

14. Shimoni A, Hardan I, Shem-Tov N, Yeshurun M, Yerushalmi R, Avigdor A, Ben-Bassat I, Nagler A: Allogeneic hematopoietic stem-cell transplantation in AML and MDS using myeloablative versus reduced-intensity conditioning: the role of dose intensity. Leukemia 2006, 20:322-328.

15. Valcarcel D, Martino R, Caballero D, Martin J, Ferra C, Nieto JB, Sampol A, Bernal MT, Pinana JL, Vazquez L, Ribera JM, Besalduch J, Moraleda JM, Carrera D, Brunet MS, Perez-Simon JA, Sierra J: Sustained remissions of high-risk acute myeloid leukemia and myelodysplastic syndrome after reduced-intensity conditioning allogeneic hematopoietic transplantation: chronic graft-versus-host disease is the strongest factor improving survival. J Clin Oncol 2008, 26:577-584.

16. Carreras E, Bertz H, Arcese W, Vernant JP, Tomas JF, Hagglund H, Bandini G, Esperou H, Russell J, de la Rubia J, Di Girolamo G, Demuynck H, Hartmann O, Clausen J, Ruutu T, Leblond V, Iriondo A, Bosi A, Ben-Bassat I, Koza V, Gratwohl A, Apperley JF: Incidence and outcome of hepatic venoocclusive disease after blood or marrow transplantation: a prospective cohort study of the European Group for Blood and Marrow Transplantation. European Group for Blood and Marrow Transplantation Chronic Leukemia Working Party. Blood 1998, 92:3599-3604.

17. McDonald GB, Hinds MS, Fisher LD, Schoch HG, Wolford JL, Banaji M, Hardin BJ, Shulman HM, Clift RA: Veno-occlusive disease of the liver and multiorgan failure after bone marrow transplantation: a cohort study of 355 patients. Ann Intern Med 1993, 118:255-267.

18. Przepiorka $D$, Weisdorf $D$, Martin $P$, Klingemann $H G$, Beatty $P$, Hows J, Thomas ED: 1994 Consensus Conference on Acute GVHD Grading. Bone Marrow Transplant 1995, 15:825-828.

19. Filipovich AH, Weisdorf D, Pavletic S, Socie G, Wingard JR, Lee SJ, Martin P, Chien J, Przepiorka D, Couriel D, Cowen EW, Dinndorf P, Farrell A, Hartzman R, Henslee-Downey J, Jacobsohn D, McDonald G, Mittleman B, Rizzo JD, Robinson M, Schubert M, Schultz K, Shulman H, Turner M, Vogelsang G, Flowers ME: National Institutes of Health consensus development project on criteria for clinical trials in chronic graft-versushost disease: I. Diagnosis and staging working group report. Biol Blood Marrow Transplant 2005, 11:945-956.

20. Gray RA: class of K-sample tests for comparing the cumulative incidence of a competing risk. Annals Of Statistics 1988, 16:1141-1154.

21. Fine JA: A proportional hazards model for the subdistribution of a competing risk. JASA 1999, 94:496-509.

22. Andersson BS, de Lima M, Thall PF, Wang X, Couriel D, Korbling M, Roberson S, Giralt S, Pierre B, Russell JA, Shpall EJ, Jones RB, Champlin RE: Once daily i.v. busulfan and fludarabine (i.v. Bu-Flu) compares favorably with i.v. busulfan and cyclophosphamide (i.v. BuCy2) as pretransplant conditioning therapy in AML/MDS. Biol Blood Marrow Transplant 2008, 14:672-684. 
23. Bredeson CN, Zhang MJ, Agovi MA, Bacigalupo A, Bahlis NJ, Ballen K, Brown C, Chaudhry MA, Horowitz MM, Kurian S, Quinlan D,

Muehlenbien CE, Russell JA, Savoie L, Rizzo JD, Stewart DA: Outcomes following HSCT using fludarabine, busulfan, and thymoglobulin: a matched comparison to allogeneic transplants conditioned with busulfan and cyclophosphamide. Biol Blood Marrow Transplant 2008, 14:993-1003.

24. Chae YS, Sohn SK, Kim JG, Cho YY, Moon JH, Shin HJ, Chung JS, Cho GJ, Yang DH, Lee JJ, Kim YK, Kim HJ: New myeloablative conditioning regimen with fludarabine and busulfan for allogeneic stem cell transplantation: comparison with BuCy2. Bone Marrow Transplant 2007, 40:541-547.

doi:10.1186/1756-8722-3-36

Cite this article as: Pidala et al:: Pharmacokinetic targeting of intravenous busulfan reduces conditioning regimen related toxicity following allogeneic hematopoietic cell transplantation for acute myelogenous leukemia. Journal of Hematology \& Oncology 2010 3:36.

\section{Submit your next manuscript to BioMed Central} and take full advantage of:

- Convenient online submission

- Thorough peer review

- No space constraints or color figure charges

- Immediate publication on acceptance

- Inclusion in PubMed, CAS, Scopus and Google Scholar

- Research which is freely available for redistribution

Submit your manuscript at www.biomedcentral.com/submit
Ciomed Central 